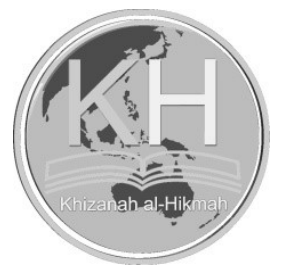

\title{
SERAH SIMPAN BUKU ELEKTRONIK: IMPLEMENTASI UNDANG-UNDANG NOMOR 13 TAHUN 2018
}

\author{
Indira Irawati*, Fathia Az'zahra* \\ *Universitas Indonesia \\ Email: sindirairawati@yahoo.com \\ (Submitted: 16-06-2019, Revised: 14-10-2019, Accepted: 01-12-2019) \\ DOI: $10.24252 /$ kah.v7i2a6
}

\begin{abstract}
ABSTRAK: Buku elektronik telah dihimpun Perpusnas sejak tahun 2016. Undang-undang yang digunakan dalam penghimpunan buku elektronik pada saat itu adalah Undang-Undang Nomor 4 Tahun 1990. Namun, undang-undang tersebut dinilai kurang kuat karena belum mencantumkan karya digital sebagai karya yang wajib diserahkan. Penelitian ini membahas tentang penerapan undang-undang serah simpan untuk buku elektronik. Penelitian ini bertujuan untuk memberi penjelasan mengenai proses serah simpan buku elektronik berdasarkan kedua peraturan yang ada. Penelitian ini menggunakan pendekatan kualitatif dengan metode studi kasus. Melalui penelitian ini, terlihat bahwa penghimpunan buku elektronik saat ini lebih gencar karena adanya undang-undang terbaru yang lebih relevan
\end{abstract}

Kata kunci: Undang-Undang Serah Simpan Karya Cetak dan Karya Rekam

\section{HAND OVER ELECTRONIC BOOKS: THE IMPLEMENTATION OF LAW NUMBER 13 OF 2018}

ABSTRACT: Electronic books have been compiled by the National Library of Indonesia since 2016. The law used in the collection of electronic books at that time was Law No. 4 of 1990. However, the law was considered to be less robust because it did not include digital works as works that must be submitted. This study discusses the application of the deposit handover law for electronic books. This study aims to provide an explanation of the process of delivering electronic books based on the two existing regulations. This research used a qualitative approach with a case study method. Through this research, it concluded that the collection of electronic books today is more intense because of the latest laws that are more

Keywords: The Law of Legal Deposit of Printed and Recorded Materials

\section{PENDAHULUAN}

Perpustakaan Nasional Republik Indonesia (PNRI) dapat dipahami sebagai perpustakaan yang bertanggung jawab atas akuisisi dan pelestarian salinan semua terbitan yang signifikan yang diterbitkan di sebuah negara dan berfungsi sebagai perpustakaan deposit, baik berdasarkan undang-undang maupun kesepakatan lain, dengan tidak memandang nama perpustakaan (Sulistyo-Basuki, 2005). Seluruh karya yang diserahkan kepada Perpustakaan Nasional dan provinsi akan disimpan dan dilestarikan agar jejak kebudayaan suatu negara dapat diketahui di masa mendatang. Hal ini sejalan dengan pernyataan dari International Federation Library Associations and Institutions (IFLA) dalam Guidelines for Legal Deposit Legislation bahwa karya-karya yang diterbitkan oleh penerbit atau pengusaha rekaman diserahkan kepada lembaga negara yang berwenang untuk dilestarikan sebagai warisan budaya bangsa (Lariviere, 2000). 
Buku elektronik telah lama diakuisisi oleh PNRI. Buku elektronik tersebut awalnya diakuisisi secara manual dalam arti penerimaannya dalam bentuk kemasan atau penyimpanan fisik, seperti di CD room atau flashdisk. Seiring perkembangan teknologi, PNRI mengembangkan sebuah sistem untuk mengelola berbagai jenis karya elektronik. Sistem tersebut bernama EDeposit yang baru saja diluncurkan pada tanggal 25 Maret 2019. Saat ini, E-Deposit sedang difokuskan untuk kegiatan serah simpan buku dan elektronik.

Fungsi deposit juga dilakukan di Australia. Perpustakaan Nasional Australia bertanggung jawab di bawah National Library Act untuk merawat dan mengembangkan koleksi nasional dari bahan pustaka, termasuk koleksi menyeluruh dari perpustakaan yang berkaitan dengan negara Australia dan orang-orang Australia. Perpustakaan menghimpun seluruh jenis karya yang diciptakan oleh warga negara Australia, seperti monograf, ephemera, sumber elektronik, peta, musik, koran, sejarah lisan, karya seni, gambar, dan terbitan berkala (National Library of Australia, 2008).

Penghimpunan buku elektronik menarik untuk diteliti karena adanya beberapa tantangan yang dihadapi Perpustakaan Nasional dalam mengumpulkan karya-karya bangsa, khususnya untuk buku elektronik. Tantangan tersebut terdiri dari pelestarian dan keamanan karya. Selain itu, terdapat peran serta wajib serah dalam menyukseskan kegiatan serah simpan seperti kesadaran, pendapat, serta konsistensi penerbit dalam penyerahan buku. Dengan demikian, diperlukan adanya upaya dari PNRI serta adanya kesadaran penerbit akan kegiatan serah simpan.

Penelitian ini membahas pelaksanaan Peraturan Serah Ssimpan di Indonesia yang dilakukan oleh PNRI terhadap buku elektronik. Peraturan yang dibahas ialah Undang-Undang Nomor 4 Tahun 1990 dan Undang-Undang Nomor 13 Tahun 2018. Kedua peraturan tersebut ditinjau dalam penelitian ini karena perubahan peraturan pasti berdampak pada proses serta hasil serah simpan buku elektronik. Tujuan dari penelitian ini untuk menjelaskan kegiatan yang dilakukan PNRI dalam melaksanakan undang-undang serah simpan. Keterbaruan dari penelitian ini adalah objek penelitiannya serta penerapan peraturan tersebut yang didukung oleh aplikasi terbaru, sehingga dapat memberikan gambaran pelaksanaan serah simpan di masa kini.

\section{KAJIAN TERDAHULU}

Beberapa penelitian terdahulu yang membahas tentang pelaksanaan deposit di PNRI. Felisha Ghassani pada tulisannya menjelaskan mengenai proses deposit karya cetak di PNRI berdasarkan Undang-Undang Nomor 4 Tahun 1990, kemudian dijelaskan pula kendala yang dihadapi oleh PNRI dalam menghimpun karya cetak. Hasil penelitian tersebut menunjukkan kendala yang dihadapi berupa biaya pengiriman, mahalnya satu salinan buku, dan sebagainya. Untuk mengatasi kendala tersebut, PNRI mengatasinya dengan bekerja sama dengan asosiasi wajib serah, penyerahan ke perpustakaan daerah, dan pemberian penghargaan. Penelitian serupa juga dilakukan oleh Ade Maretha Dwianto di mana tulisannya fokus pada surat kabar tercetak yang berada di Jakarta. Dalam penelitian tersebut, tidak hanya dibahas mengenai proses penghimpunan surat kabar, tetapi juga disertai pandangan dari wajib serah tentang kesadaran dan kepatuhan terhadap undang-undang serah simpan.

Selain penelitian di dalam negeri, kajian-kajian dari luar negeri terkait dengan deposit atau serah simpan juga pernah dilakukan. Derrot dan Koskas (2016) menyebutkan bahwa Bibliotheque nationale de France mengembangkan peraturan serah simpan pada tahun 2006 untuk mengatur penghimpunan karya digital. Ada pula laporan yang dibuat oleh International Publishers Association (2014) mengenai perubahan peraturan deposit. Inggris mengawali peraturan serah simpan dengan persetujuan antara Thomas Bodley dengan pengusahapengusaha alat tulis untuk menyerahkan buku-buku yang dijual oleh mereka ke perpustakaan. Kemudian pada abad 19 serah simpan diatur dalam peraturan hak cipta karena serah simpan berkaitan dengan hak cipta. Pada tahun 2003 barulah Inggris membuat peraturan sendiri mengenai serah simpan yaitu Legal Deposit Libraries Act 2003. Kemudian pada tahun 2013 peraturan serah simpan mengalami perkembangan lebih rinci mengenai peraturan karya elektronik luring dan daring.

\section{METODOLOGI PENELITIAN}

Penelitian ini menggunakan metode studi kasus. Metode studi kasus adalah metode yang digunakan peneliti untuk menyelidiki secara cermat suatu program, peristiwa, aktivitas, proses 
atas sekelompok individu (Creswell, 2010). Peneliti berfokus pada suatu fenomena khusus, yaitu pelaksanaan serah simpan buku elektronik. Peneliti mengumpulkan data melalui observasi lapangan dengan mencatat kegiatan yang terjadi di Subdirektorat Deposit, wawancara tak terstruktur dengan pemilihan informan menggunakan teknik purposive sampling, dan analisis dokumen dengan membandingkan pokok-pokok penting dari undang-undang serah simpan yang lama dan baru. Setelah pengumpulan data, peneliti menganalisis dengan reduksi data. Peneliti memilih hal-hal pokok yang berkaitan dengan penelitian. Kemudian data disajikan dalam bentuk narasi. Setelah itu, peneliti menarik kesimpulan berdasarkan data yang telah disajikan.

\section{HASIL DAN PEMBAHASAN}

Sebelum membahas lebih lanjut, peneliti akan memaparkan visi dan misi dari PNRI. Ada pun visi dan misinya sebagai berikut:

Visi: Terwujudnya Indonesia cerdas melalui gemar membaca dengan memberdayakan perpustakaan. Sedangkan misinya:

a) Mewujudkan koleksi nasional yang lengkap dan mutakhir.

b) Mengembangkan diversifikasi layanan perpustakaan berbasis teknologi informasi dan komunikasi (TIK).

c) Mengembangkan perpustakaan yang menjangkau masyarakat luas.

d) Mewujudkan tenaga perpustakaan yang kompeten dan profesional.

e) Menggalakkan sosialisasi/promosi/pemasyarakatan gemar membaca.

f) Mengembangkan infrastruktur perpustakaan nasional yang modern.

PNRI menjalani fungsi deposit dapat terlihat dari misinya yang pertama. Perwujudan koleksi nasional mampu tercapai melalui kegiatan serah simpan. Koleksi yang dihimpun juga termasuk koleksi elektronik. Hal tersebut dipahami dari kata "mutakhir" yang ada pada misi tersebut. "Mutakhir" dapat dipahami bahwa karya yang dihimpun keterkinian dan mengikuti perkembangan teknologi.

Landasan hukum serah simpan terdiri dari Undang-Undang dan Peraturan Pemerintah. Undang-Undang mengenai serah simpan pertama kali dikeluarkan pada tahun 1990. UndangUndang Nomor 4 Tahun 1990 Tentang Serah-Simpan Karya Cetak dan Karya Rekam dibuat atas dasar pertimbangan Undang-Undang Dasar 1945 yang mengamanatkan upaya untuk mencerdaskan kehidupan bangsa dan memajukan kebudayaan nasional.

Landasan kegiatan serah simpan perlu dibuat secara tertulis agar lebih jelas dan konsisten. Hal ini sebagaimana yang disebutkan dalam Johnson (2014) peraturan tertulis mengenai pengembangan koleksi penting untuk dimiliki oleh perpustakaan. Perpustakaan tanpa kebijakan pengembangan koleksi seperti sebuah bisnis tanpa rencana. Undang-undang serah simpan tahun 1990 ini dijadikan sebagai dasar untuk membuat berbagai peraturan seperti target serta proses penghimpunan, cara pengawasan, dan sebagainya. Semua peraturan tersebut dapat dijalankan secara terarah dan konsisten karena tertulis dengan jelas dan didasari oleh landasan hukum yang jelas pula.

Meskipun tidak ada elemen mengenai sanksi pada skema serah simpan, PNRI juga perlu melakukan penegakan serah simpan. Beberapa negara ada yang tidak memiliki peraturan khusus untuk mengatur serah simpan. Namun, sangat disarankan sebuah negara untuk mengembangkan peraturan serah simpan agar prosedur tersebut ditanggapi secara serius oleh penerbit (Lariviere, 2000).

Ketentuan mengenai sanksi dalam Undang-Undang Nomor 4 Tahun 1990 diatur dalam Pasal 11 yang berbunyi :

1) Barang siapa melanggar ketentuan sebagaimana dimaksud dalam Pasal 2, Pasal 3, Pasal 4, Pasal 6, dan Pasal 7, dipidana dengan pidana kurungan selama-lamanya 6 (enam) bulan atau pidana denda setinggi-tingginya Rp. 5.000.000,00 (lima juta rupiah).

2) Barang siapa melanggar ketentuan sebagaimana dimaksud dalam Pasal 8, dipidana dengan pidana kurungan selama-lamanya 3 (tiga) bulan atau pidana denda setinggi-tingginya Rp. 2.500.000,00 (dua juta lima ratus ribu rupiah). 
Akan tetapi, selama undang-undang tersebut berjalan, sanksi tersebut tidak pernah dilaksanakan. Penerbit yang tidak mematuhi kewajibannya, tidak pernah diproses dalam pengadilan secara hukum. Hal tersebut disebabkan oleh proses hukum pidana yang rumit serta sanksi pidana dirasa kurang membangkitkan kepatuhan hukum.

Kebijakan tertulis bukanlah sesuatu yang statis, melainkan sebuah proses yang berkelanjutan. Proses tersebut harus selalu dipersiapkan, ditinjau kembali, dan direvisi karena komunitas yang dilayani, sumber daya yang tersedia, serta sumber informasi selalu mengalami perubahan (Johnson, 2014). Undang-undang serah simpan saat ini telah mengalami perbaikan guna menyesuaikan dengan perkembangan zaman. Saat ini peraturan mengenai serah simpan diatur dalam Undang-Undang Nomor 13 Tahun 2018.

Adanya perubahan undang-undang serah simpan karena Undang-Undang Nomor 4 Tahun 1990 sudah terlalu lama, sehingga tidak sesuai dengan keadaan saat ini. Selain itu, perkembangan teknologi juga mendorong pembaruan terhadap undang-undang tersebut. Alasan lain juga berkaitan dengan pelaksanaan sanksi. Menurut pustakawan, sanksi yang tercantum tidak berjalan, sehingga perlu adanya perubahan agar pelaksanaan undang-undang serah simpan lebih efektif.

"Jadi urgensinya perubahan undang-undang nomor 4 tahun 1990 ini benar karena perkembangan teknologi digital, jadi karya-karya yang dalam format baru bisa dijangkau dengan undang-undang yang baru. Terus, undang-undang tahun 1990 udah terlalu lama, jadi tidak sesuai dengan perkembangan zaman. Alasan ketiga karena pelaksanaan pidana itu selama ini tidak berjalan. Jadi, buat apa ada sanksi pidana lagi. Makanya kita ubah. Seperti itu." (Gilang).

Kebijakan yang telah dibuat kemudian disosialisasikan ke berbagai pihak yang bersangkutan. Untuk undang-undang tahun 1990 peneliti tidak mendapatkan gambaran detail pelaksanaan sosialisasi saat undang-undang tersebut disahkan. Peneliti hanya mendapat penjelasan bahwa sosialisasi dilakukan seiring berjalannya pelaksanaan undang-undang. Perlu diketahui bahwa buku elektronik dalam undang-undang 2018 ini termasuk dalam kategori karya rekam. Buku elektronik termasuk jenis karya rekam bentuk digital. Hal tersebut diperjelas dengan pernyataan bentuk jenis karya rekam di undang-undang tersebut. Di sisi lain, ketika undang-undang 1990 masih berlaku, buku digital tidak disebutkan secara jelas, sehingga belum banyak penerbit yang mau menyerahkannya.

Perbedaan yang signifikan dari kedua undang-undang tersebut terlihat pada ketentuan sanksi yang diterapkan pada undang-undang ini. PNRI akan memberikan sanksi administratif bagi penerbit yang tidak patuh akan peraturan ini. Namun, sebelum penerbit dikenakan sanksi tersebut, PNRI akan melakukan pembinaan. Pembinaan lebih utama untuk dilakukan dari pada pemberian sanksi karena semangat yang dibawa oleh undang-undang ini berbeda. Undangundang yang baru lebih menekankan pada semangat partisipasi. Oleh karena itu, penerbit dibina agar meningkatkan kesadarannya dalam serah simpan.

Setelah adanya undang-undang serah simpan 2018, PNRI mengadakan sosialisasi secara massal di berbagai provinsi di Indonesia. Sosialisasi tersebut melibatkan berbagai pihak seperti penerbit, produsen karya rekam, lembaga pemerintah, dan asosiasi-asosiasi. Sosialisasi tersebut bertujuan untuk menyebarkan informasi terkait serah simpan, meningkatkan semangat partisipasi penerbit, dan menjadi tempat berdiskusi dengan penerbit. Sosialiasi tersebut sama seperti yang dijelaskan oleh Trinkner dan Cohn (2014). Menurut mereka para ahli sosalisasi hukum sebagian besar berfokus pada bagaimana individu memahami hukum, sistem hukum, dan perilaku kriminal.

Kegiatan yang dilakukan saat sosialisasi yaitu pemaparan materi undang-undang, Rancangan Peraturan Pemerintah (RPP), E-Deposit, dan ISBN. Materi undang-undang membahas pihak-pihak yang wajib menyerahkan, jenis karya yang harus diserahkan, waktu penyerahan, dan lain-lain sesuai dengan pasal-pasal yang tercantum. Kemudian, materi tentang RPP dijelaskan tentang rancangan proses pelaksanaan undang-undang.

Kegiatan sosialisasi dilanjutkan dengan pemaparan materi tentang E-Deposit. Pada sesi tersebut dijelaskan jenis karya yang diserahkan dan proses penyerahannya. Setelah pemaparan E-Deposit, kegiatan sosialisasi dilanjutkan dengan pemaparan mengenai ISBN. Pemaparan ini 
berisi tentang permintaan nomor ISBN untuk buku elektronik serta kewajiban penerbit untuk menyerahkannya melalui E-Deposit.

Setelah sosialisasi dilakukan, diketahui bahwa penerbit menyambut baik adanya kegiatan serah simpan ini. Hal tersebut didukung oleh semangat partisipasi dari penerbit yang ada di undang-undang baru ini. Tanggapan positif atas peraturan serah simpan ini diartikan bahwa penerbit memahami peran dan kewajibannya dalam serah simpan. Kemudian mereka juga memahami proses penyerahan buku tercetak maupun buku elektronik ke PNRI.

Penghimpunan buku elektronik telah dilakukan sejak tahun 2016. Pengumpulan ini dilakukan secara manual dengan menyerahkan secara langsung dalam bentuk fisik. Sejak awal pengumpulannya, PNRI telah mengidentifikasi terkait buku elektronik yang akan dihimpun. Tahap identifikasi ini penting untuk dilakukan agar PNRI memiliki arahan yang jelas jenis buku elektronik yang akan dihimpunnya. Selain itu, identifikasi juga mempermudah PNRI dalam mengembangkan sistem pengelolaan buku elektronik di kemudian hari.

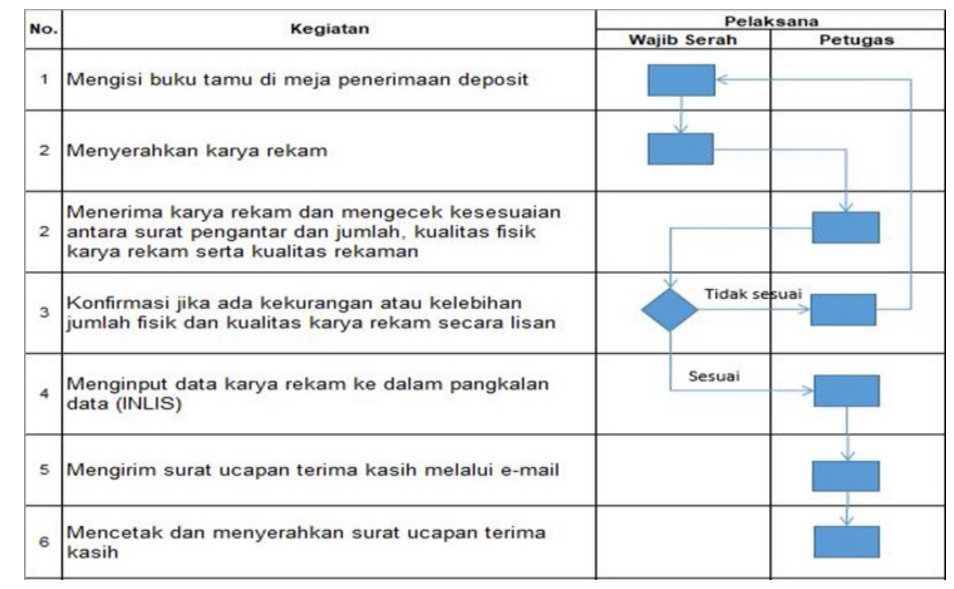

Gambar 1. Alur penyerahan buku elektronik secara manual

Pada tahap identifikasi, menurut Muir (2001) dalam De Beer (2016) PNRI perlu mengidentifikasi material apa saja yang wajib diserahkan. Mulai dari jenis terbitan, format, asal publikasinya, dan lain-lain. Berdasarkan hasil pengamatan dan wawancara dengan informan, ada beberapa kriteria buku elektronik yang dihimpun PNRI sebagai berikut:

1) Dalam format PDF

2) Bebas dari proteksi apa pun

3) Memiliki ISBN buku elektronik

Ketentuan tersebut karena ada alasan tertentu. Misalnya format pdf dipilih karena mudah digunakan dalam berbagai macam perangkat. Kemudian, buku elektronik harus bebas dari proteksi agar PNRI bisa melakukan tindakan pelestarian dengan mudah. Selain itu, buku yang memiliki ISBN wajib diserahkan karena penerbit tidak bisa meminta nomor ISBN baru jika belum menyerahkan karyanya.

Ketentuan mengenai bentuk buku elektronik ini dilakukan juga oleh Bibliotheque Nationale de France. Perpustakaan tersebut menentukan bentuk buku elektronik yang dihimpun berdasarkan analisis yang dilakukan terhadap sekelompok distributor buku elektronik. Dari analisis tersebut, ditetapkan bentuk buku elektronik yang dihimpun adalah PDF atau EPUB (Derrot \& Oury, Ebooks: rather electronic or book? Extending legal deposit to ebooks at the Bibliothèque nationale de France, 2014).

Setelah buku elektronik diidentifikasi, peneliti juga mengetahui bahwa PNRI tidak begitu banyak melakukan seleksi terhadap buku elektronik yang dihimpunnya. Menurut Muir (2001) dalam Penzohrn (2007) pada tahap seleksi perpustakaan menentukan jenis buku elektronik yang dihimpun. Namun, ada perbedaan pendapat mengenai pemilihan koleksi serah simpan. Ada pihak yang mengutamakan kelengkapan tanpa memandang nilai apa pun. 
Berdasarkan data penerimaan buku elektronik diketahui bahwa PNRI lebih mengutamakan kelengkapan dibandingkan pertimbangan nilai-nilai tertentu. PNRI menerima berbagai jenis buku elekronik, seperti novel, buku pelajaran, psikologi, dan lain-lain. Buku elektronik yang telah diterima secara manual sampai saat ini belum diolah secara lengkap. Pengolahan buku tersebut baru berjalan hingga tahap penginputan data penerimaan. Buku elektronik tersebut akan diolah bersamaan dengan buku elektronik yang langsung diserahkan melalui E-Deposit.

Saat ini pengadaan buku elektronik dilakukan melalui sistem E-Deposit. E-Deposit dibuat atas dasar hukum Undang-Undang Nomor 13 Tahun 2018 Pasal 19 yaitu "Penerimaan sebagaimana dimaksud pada ayat (1) sesuai dengan kebutuhan dan perkembangan teknologi." Penerapan fasilitas E-Deposit memungkinkan akses koleksi, metadata, katalog bersama, preservasi, dan data proteksi (Milne \& Tuck, 2008).

Cara penyerahan buku elektronik melalui E-Deposit dapat dilakukan dengan pengunggahan mandiri. Pengunggahan secara mandiri dilakukan langsung oleh penerbit yang telah memiliki akun E-Deposit. Penerbit masuk ke sistem E-Deposit menggunakan akun ISBN. Kemudian, penerbit harus melihat daftar buku elektronik yang belum diserahkan. Setelah itu, penerbit diminta untuk mengunggah file utama buku elektronik tersebut.

Menurut Muir (2001) dalam Penzohrn (2007) tugas utama yang terkait dengan pemrosesan koleksi serah simpan adalah pembuatan bibliografi nasional, penggambaran karya menggunakan standar internasional, dan pelestarian koleksi serah simpan. Berdasarkan pernyataan tersebut, diketahui bahwa metadata yang ada di sistem E-Deposit akan dijadikan acuan bagi PNRI untuk membuat bibliografi Nasional. Kemudian, bibliografi tersebut dapat dimanfaatkan bagi penerbit maupun perpustakaan lain. Bagi penerbit, bibliografi dapat dijadikan acuan untuk perdagangan buku. Bagi perpustakaan, bibliografi dapat dijadikan alat seleksi maupun acuan katalog salinan. Bibliografi Nasional ini akan disediakan dalam berbagai format.

Pemberian akses juga merupakan tahap dari pelaksanaan serah simpan. Menurut Muir (2001) dalam Penzohrn (2007) Penyediaan akses kepada publik secara gratis terhadap koleksi serah simpan adalah salah satu kegiatan inti yang terkait dengan serah simpan. Namun, undangundang tidak selalu menetapkan bahwa masyarakat memiliki hak akses ke koleksi serah simpan.

Saat ini pemberian akses buku elektronik melalui E-Deposit memang belum dijalankan. Akan tetapi, peneliti mencoba menjelaskan rencana pemberian akses tersebut berdasarkan sosialisasi E-Deposit yang telah diberikan. Buku elektronik yang telah diunggah dapat ditelusuri melalui katalog daring. Kemudian buku tersebut dapat digunakan melalui perangkat yang telah disediakan di PNRI menggunakan jaringan intranet. Pemustaka dapat mengakses setelah memasukan reader pass. Berdasarkan undang-undang dan penjelasan tersebut, PNRI melakukan pembatasan akses. Pembatasan dilakukan dengan cara menyeleksi pemustaka yang akan mendayagunakan serta proses pendayagunaan yang hanya di tempat. Untuk menjaga jalannya pelaksanaan serah simpan dengan efektif, maka perlu dilakukan pengawasan serta penegakan hukum serah simpan. Salah satu bentuk cara pengawasan yang dapat dilakukan dijelaskan oleh Penzhorn (2007) dengan melakukan survei jumlah terbitan yang diterima oleh perpustakaan.

Dalam jalannya pelaksanaan serah simpan, PNRI juga melakukan pengawasan. Kegiatan tersebut secara khusus disebut pemantauan. Pemantauan ini dilakukan dengan membandingkan jumlah buku elektronik yang diterima oleh PNRI dengan jumlah buku yang telah diterbitkan oleh suatu penerbit. Pemantauan ini dilakukan antara setahun sekali hingga dua kali. Selain mengetahui jumlah penerimaan dan penyerahan, pemantauan juga bisa memberikan gambaran perkembangan usaha penerbit tersebut. Hasil pemantauan tersebut, dapat dijadikan sebagai rujukan untuk perhitungan potensi penghimpunan di kemudian hari.

Pemantauan dengan cara mengunjungi penerbit seperti yang dilakukan PNRI juga dilakukan oleh The National Library of Nigeria. Petugas perpustakaan nasional telah mengunjungi penerbit di seluruh negara bagian untuk mensosialisasikan undang-undang serah simpan, sebagai hasil dari upaya ini, karya yang diterima tidak hanya berasal dari penerbit tetapi juga distributor buku. Penerbit pemerintah telah bekerja sama membantu mengunjungi penerbit swasta (Olanusi, 2015).

Pemantauan ini seringnya dilakukan di wilayah Jabodetabek. Di luar Jabodetabek hampir tidak pernah dilakukan pemantauan karena keterbatasan anggaran dan SDM. Menurut De Beer 
(2016) tantangan dalam penghimpunan buku elektronik seperti finansial dan ketersediaan SDM. PNRI juga menghadapi tantangan tersebut dalam melakukan pengawasan, sehingga kegiatan tersebut tidak dapat dilakukan secara menyeluruh ke berbagai wilayah.

Untuk menjamin kepatuhan, sebuah tindakan penegakan hukum harus dilakukan. Tindakan utama yang akan dilakukan PNRI dalam menegakan hukum serah simpan adalah pembinaan. Melalui pembinaan, penerbit diingatkan kembali mengenai peraturan serah simpan, manfaat, dan tujuannya. Pembinaan dilakukan untuk meningkatkan kesadaran penerbit terhadap kewajiban dan pentingnya serah simpan.

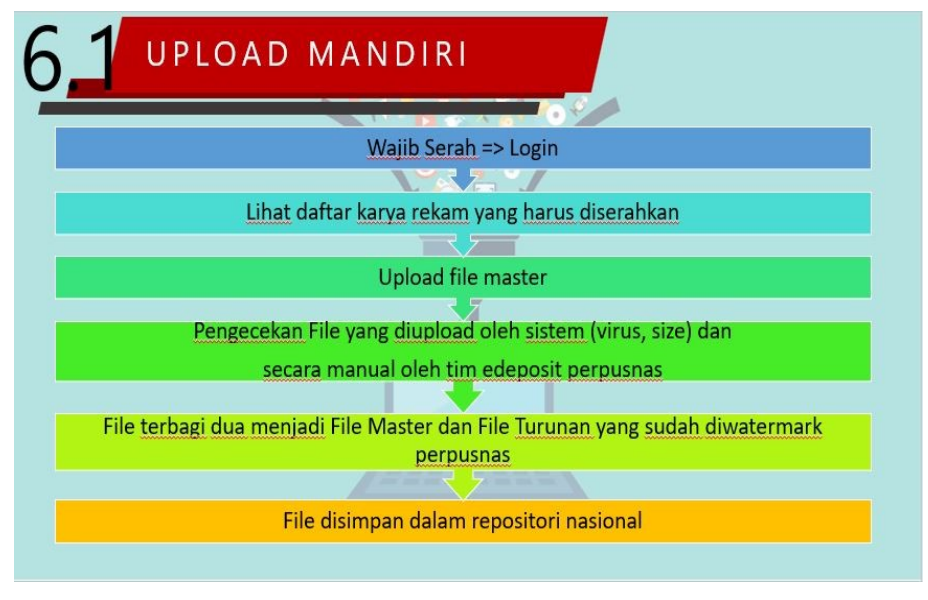

Gambar 2. Alur penyerahan buku elektronik melalui e-deposit

Selain pembinaan, ada juga sanksi yang berkaitan dengan serah simpan. Sanksi tersebut ada dari Perka Nomor 7 Tahun 2016. Sanksi yang diberlakukan pada Perka Nomor 7 Tahun 2016 tersebut serupa dengan awal serah simpan yang digagas oleh Raja Francois I dan Thomas Bodley. Awal mula serah simpan di Perancis dan Inggris dijelaskan dalam Digital Legal Deposit oleh International Publishers Association (2014).

Di Perancis Raja Francois I menyatakan bahwa tidak ada buku yang boleh dijual jika tidak diserahkan ke perpustakaan kerajaan. Hal ini kemudian diadopsi oleh Inggris. Melalui Perka tersebut, penerbit tidak akan mendapat nomor ISBN baik untuk buku elektronik maupun tercetak jika belum menyerahkan buku-buku yang telah diterbitkan. Jika tidak ada nomor ISBN, buku tersebut tidak bisa dijual karena distributor tidak mau menerimanya.

Hukuman yang berupa negosiasi seperti terkandung dalam Perka maupun undang-undang dinilai lebih efektif untuk meningkatkan kepatuhan hukum karena hal tersebut dapat mempengaruhi roda bisnis penerbit. Hal ini sejalan dengan Panzohrn (2007), mungkin lebih disarankan untuk tidak menggunakan sanksi pidana bagi penerbit yang tidak patuh. Sebaiknya gunakan upaya hukum negosiasi dan kerja sama serta kesukarelaan dari penerbit untuk mematuhi undang-undang. Hal ini secara keseluruhan dapat lebih bermanfaat bagi semua pihak yang terlibat.

Selain hukuman, ada hal lain yang dapat meningkatkan kepatuhan terhadap peraturan, yaitu melalui pemberian apresiasi. Pemberian penghargaan penting untuk dilakukan agar penerbit merasa terapresiasi atas kedisiplinannya. Selain itu, penghargaan juga bisa memotivasi penerbit lain maupun penerbit itu sendiri dalam meningkatkan kewajibannya. Penghargaan diberikan kepada penerbit yang paling mematuhi peraturan serah simpan. Pemberian penghargaan dilakukan berdasarkan tema seperti penerbit buku elektronik, surat kabar, buku elektronik bergenre tertentu, dan sebagainya. Selain kepada penerbit, penghargaan juga diberikan kepada lembaga-lembaga terkait penerbitan serta masyarakat umum yang peduli terhadap serah simpan.

Pemberian penghargaan dilakukan juga oleh The National Library of Nigeria. Penghargaan diberikan untuk lebih memotivasi penerbit agar sepenuhnya mematuhi peraturan serah simpan. Perpustakaan nasional memberikan penghargaan di bawah naungan Yayasan Buku Nasional 
pada tahun 1994. Penghargaan ini diberikan setiap tahun selama pekan buku nasional kepada penerbit yang menyetor bukunya paling banyak dan tepat waktu (Olanusi, 2015).

\section{4) DISKUSI}

Penelitian ini memberikan gambaran mengenai alur penghimpunan buku elektronik. Alur ini diadaptasi dari Muir (2001). Alur tersebut dimulai dari perencanaan yang disebut identifikasi. Kemudian dilanjutkan dengan seleksi, pengolahan, hingga pemberian akses kepada pemustaka. Dilihat dari alur tersebut, peneliti berpendapat bahwa alur ini memberikan proses penghimpunan yang lengkap, sehingga layak untuk diterapkan bagi perpustakaan. Alur ini juga dilengkapi dengan pertimbangan untuk membuat penyediaan akses. Dengan mengikuti alur tersebut, perpustakaan akan mendapatkan gambaran proses yang akan dilalui ketika menghimpun buku elektronik.

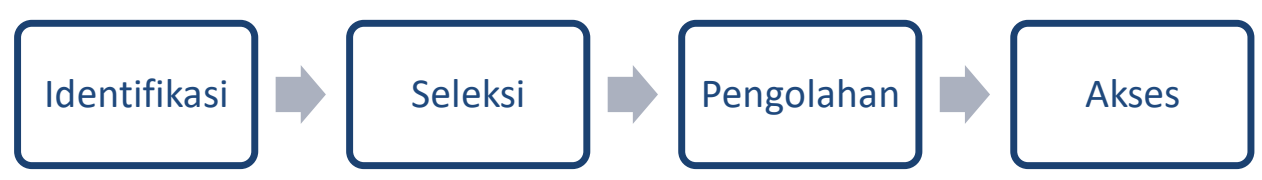

Gambar 3. Alur penghimpunan buku elektronik menurut Muir (2001)

Peneliti melihat alur seperti ini sebagian besar sudah dilakukan di PNRI. PNRI sebagai perpustakaan pembina, dapat memberi pembinaan kepada perpustakaan lain yang menghimpun koleksi elektronik, khususnya buku elektronik. Dengan pemberian pembinaan, perpustakaan akan memperoleh gambaran mengenai hal-hal yang harus disiapkan serta proses penghimpunan buku elektronik.

Selain penghimpunan, penelitian ini juga membahas cara pengawasan dan penegakan hukum. Menurut Penzohrn (2007) penegakan hukum dengan pidana dianggap kurang efektif. Hal tersebut juga telah dibuktikan dari hukum serah simpan tahun 1990 di Indonesia. Pada kenyataannya, hukum pidana tidak efektif untuk diterapkan karena dianggap rumit untuk dilakukan. Selain itu, hukum pidana juga belum tentu memberikan efek jera.

Pemberian sanksi yang dirasa lebih efektif adalah sanksi yang berkaitan dengan kegiatan bisnis penerbit. Ketika penerbit diberi sanksi yang dapat mengganggu jalannya kegiatan bisnis mereka, mereka cenderung akan mematuhi peraturan tersebut. Selain itu, pentingnya pengetahuan akan manfaat peraturan tersebut juga lebih mampu meningkatkan partisipasi penerbit dalam serah simpan.

Dari kasus tersebut, peneliti menyimpulkan bahwa sanksi pidana tidak serta merta dapat diberlakukan di berbagai kegiatan hukum. Ada cara lain yang lebih efektif untuk diterapkan agar pihak-pihak yang terkait mematuhi hukum tersebut.

\section{5) KESIMPULAN}

Penghimpunan buku elektronik telah dimulai sejak tahun 2016. Penghimpunan tersebut didasarkan atas Undang-Undang Nomor 4 Tahun 1990. Akan tetapi, hukum tersebut kurang kuat dijadikan landasan serah simpan buku elektronik. Hal tersebut disebabkan oleh undang-undang yang tidak mencantumkan bentuk digital, sehingga penerbit memiliki penafsiran yang berbeda. Atas pertimbangan kemajuan teknologi, pelaksanaan sanksi yang tidak efektif, dan pendekatan peraturan yang berbeda, maka dibuatlah Undang-Undang Nomor 13 Tahun 2018.

Adanya perubahan tersebut mempengaruhi jalannya deposit buku elektronik di PNRI. Saat ini, buku elektronik yang terhimpun lebih banyak karena adanya kemudahan penyerahan melalui E-Deposit. Selain itu, ada pula pengawasan yang dilakukan satu hingga dua kali dalam setahun. Setelah dilakukan pengawasan, PNRI akan menjalankan pembinaan bagi penerbit yang kurang disiplin. Jika, pembinaan tidak berhasil, maka akan diberlakukan sanksi administratif.

Adanya E-Deposit, pembinaan, serta sanksi administratif dapat mempermudah jalannya deposit buku elektronik. Melalui E-Deposit penerbit tidak perlu mengeluarkan biaya pengiriman. Adanya pembinaan dapat meningkatkan kesadaran penerbit akan pentingnya deposit. Sanksi administratif yang diberlakukan juga bersinggungan dengan kegiatan usahanya, sehingga penerbit lebih terdorong untuk berpartisipasi agar kegiatan usahanya tetap berjalan. 


\section{DAFTAR PUSTAKA}

Beer, M. D., Merwe, M. V., Ball, L., \& Fourie, I. (2016). Legal deposit of electronic books - a review of challenges faced by national libraries . Library Hi Tech, 87-103.

Creswell, J. W. (2010). Research design: pendekatan kualitatif, kuantitatif, dan mixed. Yogyakarta: Penerbit Pustaka Pelajar.

Derrot, S., \& Koskas, M. (2016). My fair metadata: cataloging legal deposit ebooks at the national library of france. Cataloging \& Classification Quarterly, 583-592.

Derrot, S., \& Oury, C. (2014). Ebooks: rather electronic or book? Extending legal deposit to ebooks at the Bibliothèque nationale de France. IFLA World Library and Information Congress (pp. 1-10). Lyon: HAL: archives-ouvertes.fr.

International Publishers Association. (2014). Digital legal deposit. International Publishers Association. Retrieved from https://www.internationalpublishers.org/images/news/2014/digital-legaldeposit-2014.pdf

Johnson, P. (2014). Fundamentals of collection development and management (3rd ed.). Chicago: ALA.

Landry, P. (2017). National libraries' functions : results from the 2016 survey of national libraries' functions. IFLA WLCI 2017 (pp. 1-7). Wroclaw: IFLA.

Lariviere, J. (2000). Guidelines for legal deposit legislation. Paris, France: UNESCO. Retrieved from https://www.ifla.org/files/assets/nationallibraries/publications/guidelines-for-legal-deposit-legislation-en.pdf

Milne, R., \& Tuck, J. (2008, October 30). Implementing e-legal deposit : a british library perspective. Retrieved from Ariadne : web megazine for information professional: http://www.ariadne.ac.uk/issue/57/milne-tuck/

Olanusi, A. E. (2015, April \& July). An evaluation of legal deposit laws of the national library of nigeria: enforcement, benefit and challenge. Information Studies, 21(2\&3), 167-179. Retrieved from https://remotelib.ui.ac.id:2155/docview/1735881621?pq-origsite=summon

Penzhorn, C. E. (2007). The implementation, monitoring, and management of an effective legal deposit system for south africa. Pretoria: University of Pretoria.

Sulistyo-Basuki, S. (2005, Juni). Asal usul serta fungsi Perpustakaan Nasional. Visi Pustaka, 07(1). Retrieved from https://www.PNRI.go.id/magazinedetail.php?lang=id\&id=8044\#tab-2

Trinkner, R., \& Cohn, E. S. (2014). Putting the "social" back in legal socialization: procedural justice, legitimacy, cynicism in legal and nonlegal authorities. American Psychological Association, 38(6), 602-617. 